\title{
Organizational Characteristics, Individual Characteristics, Work Characteristics, and Technological Factors against Culture-Based Care
}

\author{
Agusta Ellina (i), Nursalam Nursalam*(i), Esti Yunitasari(i) \\ Department of Nursing, Faculty of Nursing, Universitas Airlangga, Surabaya, Indonesia
}

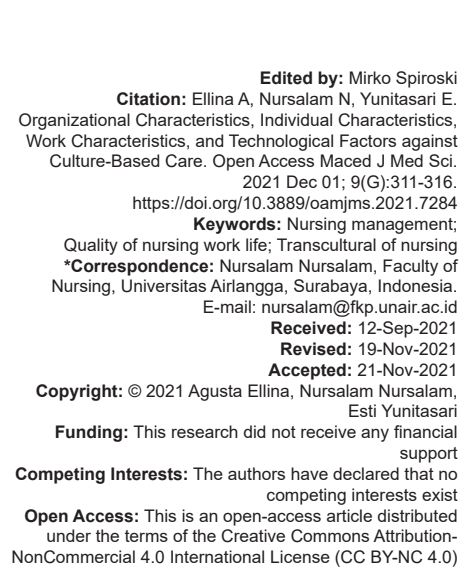

\section{Introduction}

The quality of nursing services has a direct impact on the level of client satisfaction. The marketing wave of health services has now changed from the era of service excellence to the era of care with character so that caring behavior becomes the main principle in the quality of nursing and health services in general [1]. Caring behavior is the main indicator in the quality of health services [2]. Caring as an evaluation of health services is a trend in the present era [3]. Caring is also the main performance of nurses as an effort to improve service quality [1].

Several studies have stated that caring behavior cannot be implemented optimally because it is influenced by several aspects, one of which is the cultural aspect. Aspects of caring behavior that have been used so far have not been integrated with cultural aspects which include religious, socio-cultural, educational, economic, and motivational factors, so that it has an impact on the quality of nursing work life (QNWL) in providing services. Until now, the influence of the culture-based caring model on QNWL and the quality of nursing services are unknown [4].

Caring has a big impact on service quality. Based on the data owned by the Regional General Hospital Dr. Iskak Tulungagung and Blambangan Regional General Hospital Banyuwangi starting 2016, 2017 , and 2018 stated that the satisfaction rate with the quality of nursing services was still below $80 \%$. In 2018, the client satisfaction rate with the quality of nursing services tends to decrease from $79 \%$ in 2017 to $77 \%$ in 2018 . The emerging issue in the present era states that the decline in satisfaction rates with the quality of nursing services is directly proportional to the decrease in the quality of caring received by clients [3].

Nurses admit that it is difficult to implement caring behavior because of the diverse cultural backgrounds of the clients being treated and the nurses themselves; this has a negative influence on service quality in nursing services. This cultural gap will result in culture shock and culture imposition; of course it will also affect the quality of caring in local hospitals so that the quality of nursing services in the past 3 years is 
still below $80 \%$. This figure is still below the government standard of more than $85 \%$.

Ayala and Calvo revealed that there are not many studies in the world that prove the optimal application of caring in countries that are rich in cultural diversity [5]. Meanwhile, research on transcultural care that has been published in Indonesia itself has only been carried out in community nursing, namely, on HIV Stigma [6]. Based on the data obtained from the medical records of the Regional General Hospital Dr. Iskak Tulungagung and Blambangan Regional General Hospital Banyuwangi 2016-2018 found that the clients came from several different cultures. The problem of nurses in caring for culturally diverse clients is a difficult challenge to deal with [7]. Nurses' knowledge and understanding of the client's culture are an important factor in carrying out caring behavior to prevent culture shock and culture imposition. Cultural shock occurs when outsiders (nurses) try to learn or adapt effectively to certain cultural groups (clients) [4].

According to the Gillham et al., research on caring that uses a culturally sensitive approach also needs to be carried out on communities/clients from diverse cultures or cross-culturalities who live side by side in an area and do not focus on those who are culturally sensitive [8]. According to the Purnell (2018), until now in many developing countries, caring is still interpreted in general as a sense of empathy only and without regard to cultural background, therefore, research on cultural-based caring in cross-cultural societies still needs to be developed. This study aims to develop a culture-based caring model by integrating the cultural aspects of the trascultural care theory (maintenance, negotiation, and restructuring) into the caring aspects of Swanson's caring theory, so that nurses are expected to not only interpret caring as mere empathy and have an impact on increasing nursing service quality [9].

Efforts to answer the above problems need a new model of caring that uses a transcultural care theory approach, so that the caring given by a nurse in carrying out her duties and functions can be fully accepted by the client optimally, with this it is hoped that the client will feel a quality service. The previous studies on cultural caring focused only on different people who are culturally sensitive. This study uses service quality development theory as a frame of mind, because caring is part of performance (work behavior) to improve service quality (Organization Effectiveness). Caring skills in this study use the caring concept of Swanson. Swanson argues that caring is closely related to the philosophical behavior of nurses and the performance of nurses, namely, always providing information, understanding, conveying messages, taking therapeutic actions, and always expecting good end results [10]

\section{Methods}

This research is a quantitative research using a cross-sectional approach. This research has been conducted at the Regional General Hospital Dr. Iskak Tulungagung and the Blambangan Regional General Hospital Banyuwangi. The research was carried out in July 2020-October 2020. The respondents involved in this study were 180 respondents with the following criteria: a) Inpatient nurses, b) having 2 years of work experience, and c) a minimum education diploma in nursing. The research variables are organizational characteristics, individual characteristics, work characteristics, technological factors, culture-based caring, QNWL, and quality of nursing services. Organizational characteristics questionnaire consists of hospital policy, reward system, and training [11] and organizational culture [12]. The individual characteristics questionnaire consists of religious factors [13], sociocultural [14], economy [11], motivation [15], and education level. Questionnaire work characteristics consist of work schedule [11], job design [11], and feedback [11]. The technological factor questionnaire consists of the use of technology and the use of social media. The culturebased caring questionnaire consists of upholding trust, compassion, and competence [10], [16]. QNWL questionnaire consists of work life-home life dimension, work design dimension, work context dimension, and work world dimension [11]. The data in this study were analyzed using quantitative analysis techniques using SEM PLS. This research has been approved by the Health Research Ethics Commission of the Regional General Hospital DR. Iskak Tulungagung No: 070/2695/407.206/2020.

\section{Results}

\section{Characteristics of respondents}

The results of the study in Table 1 show that the age of the respondents with the largest portion is in the age range of $21-40$ years $(52.8 \%)$, the most of the respondents $(62.6 \%)$ are female nurses, and the monthly income is more than Rp. 5,000,000.00 (51.7\%). Respondents in this study have a fairly good education; almost half of the respondents $(48.9 \%)$ have undergraduate education. More than half of the respondents $(56.7 \%)$ have permanent employee status where they work. In terms of years of service, the most of the respondents $(59.4 \%)$ had more than 3 years of service. Respondents who participated in this study came from several diverse ethnic groups, the largest portion came from the Arek Javanese (25\%), followed by the Panaragan (17.2\%), Osing (16.1\%), Mataraman 
(14.4\%), Madurese (13.3\%), Balinese (3.9\%), Sundanese (3.3\%), Minang (3.3\%), Betawi (1.7\%), and the last is the Dayak (1.7\%).

Table 1: Characteristics of respondents

\begin{tabular}{|c|c|c|}
\hline Characteristics of respondents & $f$ & $\%$ \\
\hline \multicolumn{3}{|l|}{ Age } \\
\hline $21-40$ years & 95 & 52.8 \\
\hline $41-60$ years & 85 & 47.2 \\
\hline Total & 180 & 100 \\
\hline \multicolumn{3}{|l|}{ Gender } \\
\hline Male & 68 & 37.8 \\
\hline Female & 112 & 62.2 \\
\hline Total & 180 & 100 \\
\hline \multicolumn{3}{|l|}{ Income/month } \\
\hline$\leq$ Rp. 5.000 .000 & 87 & 48.3 \\
\hline >Rp. 5.000 .000 & 93 & 51.7 \\
\hline Total & 180 & 100 \\
\hline \multicolumn{3}{|l|}{ Education level } \\
\hline Nursing diploma & 92 & 51.1 \\
\hline Ners & 88 & 48.9 \\
\hline Total & 180 & 100 \\
\hline \multicolumn{3}{|l|}{ Employee status } \\
\hline Employee status & 102 & 56.7 \\
\hline Temporary employees & 78 & 43.3 \\
\hline Total & 180 & 100 \\
\hline \multicolumn{3}{|l|}{ Length of working } \\
\hline $2-3$ year & 73 & 40.6 \\
\hline$>3$ years & 107 & 59.4 \\
\hline Total & 180 & 100 \\
\hline \multicolumn{3}{|l|}{ Ethnicity } \\
\hline Panaragan & 32 & 17.2 \\
\hline Jawa Arek & 45 & 25 \\
\hline Osing & 29 & 16.1 \\
\hline Madura & 24 & 13.3 \\
\hline Mataraman & 26 & 14.4 \\
\hline Betawi & 3 & 1.7 \\
\hline Minang & 6 & 3.3 \\
\hline Bali & 7 & 3.9 \\
\hline Sunda & 6 & 3.3 \\
\hline Dayak & 3 & 1.7 \\
\hline Total & 180 & 100 \\
\hline
\end{tabular}

\section{Organizational characteristic}

Organizational characteristic has four variable indicators, including hospital policy, reward system, organizational culture, and training. Table 2 shows that the hospital policy indicator is still found in the bad category of $20.6 \%$, the most powerful parameter in explaining hospital policy in this study is the organizational structure. The reward system indicator is also still found in the bad category of $22.8 \%$, this reward system can mostly be explained by the reward factor. The organizational culture indicator was found to be $38.9 \%$ in the bad category and $25.6 \%$ in the training indicator in the bad category.

Table 2: Description of Organizational Characteristics at the Regional General Hospital Dr. Iskak Tulungagung and the Blambangan Banyuwangi Regional General Hospital in 2020 $(n=180)$

\begin{tabular}{llll}
\hline Organizational characteristic & Classification & $\mathrm{f}$ & $\%$ \\
\hline Hospital policy & Poor & 37 & 20.6 \\
& Moderate & 71 & 39.4 \\
& Good & 72 & 40 \\
Reward system & Total & 180 & 100 \\
& Poor & 41 & 22.8 \\
& Moderate & 67 & 37.2 \\
Organizational culture & Good & 72 & 40 \\
& Total & 180 & 100 \\
& Poor & 70 & 38.9 \\
& Moderate & 95 & 52.8 \\
Training & Good & 15 & 8.3 \\
& Total & 180 & 100 \\
& Poor & 46 & 25.6 \\
& Moderate & 22 & 12.2 \\
& Good & 112 & 62.2 \\
& Total & 180 & 100 \\
\hline
\end{tabular}

\section{Individual characteristics}

Individual characteristic has five variable indicators, including religious, socio-cultural, economic, motivational, and educational factors. Table 3 shows that the indicator of religious factors is still found in the bad category of $21.1 \%$, the strongest parameter in explaining religious factors is belief. Economic indicators are also still found in the economic category of $<22.8 \%$, the amount of salary is the most powerful parameter in explaining economic factors. Socio-cultural indicators were found to be $41.7 \%$ in the bad category and $47.8 \%$ in the motivational indicator in the moderate category. More than half of the respondents still have a diploma 3 educations (51.1\%).

Table 3: Description of Individual Characteristics at the Regional General Hospital Dr. Iskak Tulungagung and the Blambangan Banyuwangi Regional General Hospital in 2020 ( $n=180)$

\begin{tabular}{llll}
\hline Individual characteristics & Classification & f & $\%$ \\
\hline Religious factor & Poor & 38 & 21.1 \\
& Moderate & 65 & 36.1 \\
& Good & 77 & 42.8 \\
Socio-cultural & Total & 180 & 100 \\
& Poor & 75 & 41.7 \\
& Moderate & 17 & 9.4 \\
& Good & 88 & 48.9 \\
Economy & Total & 180 & 100 \\
& Poor & 41 & 22.8 \\
& Moderate & 67 & 37.2 \\
Motivation & Good & 72 & 40 \\
& Total & 180 & 100 \\
& Weak & 6 & 3.3 \\
& Moderate & 86 & 47.8 \\
Education level & Strong & 88 & 48.9 \\
& Total & 180 & 100 \\
& 3-year diploma & 92 & 51.1 \\
& Ners & 88 & 48.9 \\
& Total & 180 & 100 \\
\hline
\end{tabular}

\section{Work characteristic}

Table 4 explains that the work characteristics are perceived as follows; work schedule $(23.3 \%)$ is in the bad category, the convenience of the official schedule is the strongest parameter in explaining the work schedule. Job design (26.1\%) is also still in the bad category; job descriptions have the largest portion in explaining job design. Feedback $(36.7 \%)$ is still in the bad category; responsibility is the strongest parameter in explaining feedback.

Table 4: Description of Work Characteristics at the Regional General Hospital Dr. Iskak Tulungagung and the Blambangan Banyuwangi Regional General Hospital in $2020(n=180)$

\begin{tabular}{llll}
\hline Work characteristic & Classification & $\mathrm{f}$ & $\%$ \\
\hline Work schedule & Poor & 42 & 23.3 \\
& Moderate & 11 & 6.1 \\
& Good & 127 & 70.6 \\
Job design & Total & 180 & 100 \\
& Poor & 47 & 26.1 \\
& Moderate & 13 & 7.2 \\
& Good & 120 & 66.7 \\
Feedback & Total & 180 & 100 \\
& Poor & 66 & 36.7 \\
& Moderate & 13 & 7.2 \\
& Good & 101 & 56.1 \\
& Total & 180 & 100 \\
\hline
\end{tabular}

\section{Technological factor}

Table 5 describes the technological factors perceived as follows; the use of technology $(36.7 \%)$ is 
in the low category, and the use of social media $(30 \%)$ is in the low category.

Table 5: Description of Technological Factors at the Regional General Hospital Dr. Iskak Tulungagung and the Blambangan Banyuwangi Regional General Hospital in $2020(n=180)$

\begin{tabular}{llll}
\hline Job factor & Classification & $\mathrm{f}$ & $\%$ \\
\hline Technology utilization & Poor & 66 & 36.7 \\
& Moderate & 5 & 2.8 \\
& Good & 109 & 60.6 \\
Social media utilization & Total & 180 & 100 \\
& Poor & 54 & 30 \\
& Moderate & 7 & 3.9 \\
& Good & 119 & 66.1 \\
& Total & 180 & 100 \\
\hline
\end{tabular}

\section{Culture-based caring}

Caring based on culture has three variable indicators, including upholding trust, compassion, and competence. Table 6 shows that the indicator of upholding trust is still found in the bad category of $21.1 \%$, the strongest parameter in explaining upholding trust is maintenance. The compassion indicator was found in the bad category at $32.2 \%$, negotiation being the strongest parameter in explaining compassion. The competency indicator was also found at $31.1 \%$ in the bad category; the strongest parameter in explaining competition was restructuring.

Table 6: Description of Culture-Based Caring at the Regional General Hospital Dr. Iskak Tulungagung and the Blambangan Banyuwangi Regional General Hospital in $2020(n=180)$

\begin{tabular}{llll}
\hline Culture-based caring & Classification & $\mathrm{f}$ & $\%$ \\
\hline Upholding trust & Poor & 38 & 21.1 \\
& Moderate & 87 & 48.3 \\
& Good & 55 & 30.6 \\
Compassion & Total & 180 & 100 \\
& Poor & 58 & 32.2 \\
& Moderate & 7 & 3.9 \\
& Good & 115 & 63.9 \\
Competance & Total & 180 & 100 \\
& Poor & 56 & 31.1 \\
& Moderate & 12 & 6.7 \\
& Good & 112 & 62.2 \\
& Total & 180 & 100 \\
\hline
\end{tabular}

\section{QNWL}

QNWL has four variable indicators, including work life-home life dimensions, work design dimensions, work context dimensions, and work world dimensions. The Table 7 shows that the work life-home life dimensions indicator was found to be in the poor category $37.2 \%$, the work design dimensions indicator was found to be $27.8 \%$ in the poor category, the work context dimensions indicator was found to be $49.4 \%$ in the poor category, and the work world dimensions indicator found $45.5 \%$ in the poor category, the public's view of the nursing profession has the largest portion in explaining work world dimensions.

\section{Structural equation model analysis}

The results of Table 8 explain that organizational characteristics can increase culture-based caring behavior
(T-statistics $=4.368$ and $\mathrm{p}$ value $=0.000)$, but cannot increase QNWL (T-statistics = 1.152 and p-value $=0.250)$. Individual characteristics can increase culture-based caring behavior (T-statistic $=11,132$ and $p$ value $=0.000$ ), and can increase QNWL (T-statistic $=3.927$ and p-value $=0.000$ ). Work characteristics can increase culture-based caring behavior (T-statistic $=3.827$ and $p$ value $=0.000$ ), but cannot increase QNWL (T-statistic $=1.481$ and $p$ value $=0.139)$. Technological factors can increase the behavior of culture-based caring ( $T$-statistics $=2.899$ and $p$ value $=0.004)$, and can increase QNWL (T-statistics = 2.433 and $p$ value $=0.015)$. Culture-based caring can increase QNWL (T-statistic $=11.972$ and $p$ value $=0.000)$.

Table 7: Description of QNWL in Regional General Hospital Dr. Iskak Tulungagung and Blambangan Hospital Banyuwangi in $2020(n=180)$

\begin{tabular}{llll}
\hline QNWL & Classification & $\mathrm{f}$ & $\%$ \\
\hline Work life-home life dimensions & Poor & 67 & 37.2 \\
& Moderate & 98 & 54.5 \\
& Good & 15 & 8.3 \\
Work design dimensions & Total & 180 & 100 \\
& Poor & 50 & 27.8 \\
& Moderate & 118 & 65.5 \\
& Good & 12 & 6.7 \\
Work context dimensions & Total & 180 & 100 \\
& Poor & 89 & 49.4 \\
& Moderate & 85 & 47.3 \\
Work world dimensions & Good & 6 & 3.3 \\
& Total & 180 & 100 \\
& Poor & 82 & 45.5 \\
& Moderate & 91 & 50.6 \\
& Good & 7 & 3.9 \\
\hline ONWL: Quality of nursing work life & Total & 180 & 100 \\
\hline
\end{tabular}

\section{Discussion}

The results of statistical tests showed that individual characteristics significantly affected culturebased caring and QNWL directly. This study is in line with the opinion of Enestvedt and Clark which says that the individual characteristics of nurses will greatly determine the quality of caring given to their patients. The results also show that individual characteristics are formed by several indicators, namely, religious, socio-cultural, economic, motivational, and educational factors [4]. The results of this study are also in line with the opinion of Kopelman which says that motivation and values/norms can characterize a particular individual in performing services, so this will also greatly determine how much quality of service is provided [17].

The results of statistical tests showed that work characteristics significantly affected culture-based caring but could not directly affect QNWL. This study is in line with the opinion of Robbins and Coulter which says that the work characteristics and workload of nurses will greatly determine the quality of caring given to their patients. The results of the study also showed that the work characteristic of nurses was formed by several indicators, namely, the duty schedule, clarity of main tasks and functions (job design), and feedback provided by leaders and institutions [18]. 
Table 8: Path coefficients - Bootstrap

\begin{tabular}{|c|c|c|c|c|c|c|}
\hline Influence between variables & Original Sample (O) & Sample Mean (M) & Standard Deviation (STDEV) & T-statistics & p-values & Significance \\
\hline Organizational Characteristics -> Culture-Based Caring & 0.719 & 0.734 & 0.165 & 4.368 & 0.000 & Significant \\
\hline Organizational Characteristics -> QNWL & 0.135 & 0.148 & 0.017 & 1.152 & 0.250 & Not Significant \\
\hline Individual Characteristics -> Culture-Based Caring & 0.906 & 0.904 & 0.160 & 11.132 & 0.000 & Significant \\
\hline Individual Characteristics -> QNWL & 0.954 & 0.933 & 0.188 & 3.927 & 0.000 & Significant \\
\hline Work Characteristics -> Culture-Based Caring & 0.480 & 0.489 & 0.125 & 3.827 & 0.000 & Significant \\
\hline Work Characteristics -> QNWL & 0.119 & 0.132 & 0.080 & 1.481 & 0.139 & Not Significant \\
\hline Technological Factors -> Culture-Based Caring & 0.282 & 0.290 & 0.197 & 2.899 & 0.004 & Significant \\
\hline Tech Factor $>$ QNWL & 0.150 & 0.154 & 0.162 & 2.433 & 0.015 & Significant \\
\hline Culture Based Caring $->$ QNWL & 0.160 & 0.185 & 0.181 & $11.972^{*}$ & 0.000 & Significant \\
\hline
\end{tabular}

T-statistic value $\geq 1.96, p=\leq 0.05$

Statistical test results show that technology factors can significantly influence culture-based caring and QNWL directly. This study is in line with the opinion of Enestvedt and Clark which says that the ability of nurses to utilize appropriate technology will greatly determine the quality of caring given to their patients. The results also show that the technological factor is formed by two indicators, namely, the use of technology and the use of social media [4].

Statistical test results show that culture-based caring in this study can significantly affect QNWL. Culturebased caring can be influenced by several factors, namely, organizational characteristics, individual characteristics, job characteristics, and technological factors. The results also show that culture-based caring can be formed by three indicators, namely, upholding trust, compassion, and competence. The results of this study are in line with the research of Sacco and Copel which explains that caring is the main performance of nurses as an effort to improve the quality of service and the quality of nurses' work life [1]. Caring behavior is the main indicator in the quality of health services [2]. Several studies state that caring behavior cannot be implemented optimally because it is influenced by several aspects, one of which is the cultural aspect [4]. Ayala and Calvo revealed that there are not many studies in the world that prove the optimal application of caring in countries that are rich in cultural diversity [5]. Markey et al. say that the problem of nurses in caring for culturally diverse clients is a difficult challenge to face [7]. Kalfoss and Owe Cand say that the wave of marketing health services has now changed from the era of service excellence to the era of care with character so that caring behavior is the main principle in the quality of nursing and health services in general [19]. Transcultural nursing is a major direction in nursing that focuses on the comparative study and analysis of different cultures and sub-cultures in the world that value caring behaviors, nursing services, values, beliefs about health and illness, and behavioral patterns aimed at developing scientific and humanistic body of knowledge to place nursing practice in a particular culture and universal culture [16].

\section{Conclusion}

Organizational characteristics cannot increase QNWL directly, but mediation is needed through culture-based caring to achieve positive QNWL. Individual characteristics can improve QNWL through religious, socio-cultural, economic, motivational, and educational factors. Work characteristics cannot increase QNWL directly, but mediation is needed through culture-based caring to achieve positive QNWL. Technological factors can improve QNWL through the use of technology and the use of social media.

\section{References}

1. Sacco TL, Copel LC. Compassion satisfaction: A concept analysis in nursing. Nurs Forum. 2018;53(1):76-83. https://doi. org/10.1111/nuf. 12213

PMid:28662300

2. Dudkiewicz PB. Utilizing a caring-based nursing mode in an interdepartmental setting to improve patient satisfaction. Int J Hum Caring. 2014;18(4):30-3. https://doi. org/10.20467/1091-5710-18.4.30

3. Hogg R, Hanley J, Smith P. Learning lessons from the analysis of patient complaints relating to staff attitudes, behaviour and communication, using the concept of emotional labour. J Clin Nurs. 2018;27(5-6):e1004-12. https://doi.org/10.1111/ jocn. 14121

PMid:29052343

4. Enestvedt RC, Clark KM. Caring in the margins: A scholarship of accompaniment for advanced transcultural nursing practice. ANS Adv Nurs Sci. 2018;41(3):230-42. https://doi.org/10.1097/ ANS.0000000000000201

PMid:29474227

5. Ayala RA, Calvo MJ. Cultural adaptation and validation of the caring behaviors assessment tool in chile. Nurs Health Sci. 2017;19(4):459-66. https://doi.org/10.1111/nhs.12364 PMid:28816395

6. Sismulyanto $S$, Supriyanto S, Nursalam N. Model to reduce HIV related stigma among Indonesian nurses. Int J Public Health Sci. 2015;4(3):184-91.

7. Markey K, Tilki M, Taylor G, Lecturer P. Understanding nurses concerns when caring for patients from diverse cultural and ethnic backgrounds. J Clin Nurs. 2018;27(1-2):e259-68. https:// doi.org/10.1111/jocn.13926

PMid:28618101

8. Gillham D, De Bellis A, Xiao L, Willis E, Harrington A, Morey W, et al. Using research evidence to inform staff learning needs in cross-cultural communication in aged care. Nurse Educ Today. 2018;63:18-23. https://doi.org/10.1016/j.nedt.2018.01.007 PMid:29407255

9. Purnell L. Update: The purnell theory and model for culturally competent health care J Transcult Nurs. 2019;30(2):98-105. https://doi.org/10.1177/1043659618817587 
PMid:30567469

10. Swanson K. Assesing and Measuring Caring in Nursing and Health Science. $2^{\text {nd }}$ ed. New York: Springer Publishing Company, LLC; 2009.

11. Nursalam N. Metodologi Penelitian IImu Keperawatan Pendekatan Praktis. $4^{\text {th }}$ ed. Jakarta, Selatan: Salemba Medika; 2015.

12. Robbins SP, Judge TA. Organizational Behavior. $15^{\text {th }}$ ed. New York: Pearson Prentice Hall; 2013.

13. Zwingmann $\mathrm{C}$, Büssing $\mathrm{A}$, Klein $\mathrm{C}$. Measuring religiosity/ spirituality: Theoretical differentiations and categorization of instruments. Roligios. 2011;2:345-57. https://doi.org/10.3390/ rel2030345

14. Roney LN, Acri MC. The cost of caring: An exploration of compassion fatigue, compassion satisfaction, and job satisfaction in pediatric nurses. J Pediatr Nurs. 2018;40:74-80. https://doi.org/10.1016/j.pedn.2018.01.016
PMid:29402658

15. Nursalam N, Wijaya A, Bakar A, Efendi F. Indonesian nursing students in caring behavior. J Ners. 2015;2(2):45-8.

16. Leininger $M$. Culture care theory: A major contribution to advance transcultural nursing knowledge and practices. J Transcult Nurs. 2002;13(3):189-92; discussion 200-1. https:// doi.org/10.1177/10459602013003005

PMid:12113148

17. Kopelman RE. Managing Productivity in Organizations : A Practical, People-Oriented Perspective. New York, United States: McGraw-Hill; 1986.

18. Stephen MC, Robins P. Management. $11^{\text {th }}$ ed., Vol. 40. Boston: Prentice Hall; 2012.

19. Kalfoss M, Owe J. Empirical verification of swanson's caring processes found in nursing actions: Systematic review. Open J Nurs. 2015;5:976-86. 